\title{
In Searching Architecture and City Pattern as the Mark of Old Coastal Semarang, Indonesia
}

\author{
R. Siti Rukayah¹, Muhammad Abdullah² \\ ${ }^{1}$ Department of Architecture, Faculty of Engineering, Universitas Diponegoro, Indonesia \\ ${ }^{2}$ Department of Bahasa Indonesia, Faculty of Cultural Studies, Universitas Diponegoro, Indonesia
}

Corresponding e-mail: sitirukayah.tutut@gmail.com

\section{Article info:}

Received: 25-03-2021, Revised: 14-04-2021, Accepted: 17-04-2021

\begin{abstract}
Based on the previous research on the former of Semarang capital city, Kanjengan, there is a supposition that the area is a coastal city. As the consequence of the sedimentation process occurred by Java Island, Semarang city, and some cities in Java are no longer on the seashore. The cities that are archived in the Map of Indonesia in the 15th century and some records from foreign sailors, absolutely have several different conditions compared to the past and the present condition. How the architecture and the city's patterns of the Old Semarang? The method of this research was conducted by exploring historical articles, toponyms, maps, and old pictures which were then compared with the remaining architecture and spatial patterns. The reading of old maps and pictures was done by using the seeing by believing approach. The analysis was performed by using the manual sketch. The architectural heritage like the former lighthouse, commercial corridors in the north of the square, and toponyms were tools to prove that the area was a seaport and a waterfront city. Old Coastal Semarang has an Architecture and urban design concept as the main gate from the sea to the city center at the time. Surrounding the main gate, they were the existence of the former lighthouse (the Menara Layur Mosque), multi-ethnics houses, toponyms indicating that some places were a former harbor, and the remaining trade corridor connecting the port and the local government center. This concept is similar to the Islamic Sultanates on the north coast of Java and the waterfront-based cities in the interior of Java. It is assumed that Semarang Old city has a similar role with the other Islamic Sultanates. This area is proper to be a city conservation area and become a part that is integrated into future urban planning.
\end{abstract}

Keywords: The remaining architecture, urban design, coastline, Semarang, heritage

\section{Introduction}

The contribution of the research is to fill the gap of knowledge about the coastal heritage area that has not been detailed in Law No. 32 of 2014. On the other hand, if we talk about the importance of cultural heritage values, it is not related to a group of people in a particular geographic location, but it means all the cultural significance that is shared by different cultures in different geographic locations in the world. (Rouhi, 2017).

The old city of Semarang based on previous research found that the city is located on the coast in the 14-15 century. At that time, Semarang city was speculated located on the coastline (Bemmelen, 1948). However, at the present, the old city of Semarang is located in the middle of the city. It is related to the research issue backed by the occur of abrasion and accretion process by the coastal area in Java (Sardiyatmo, 2013) and issue planning, utilization, supervision and control from the Department of Marine Affairs and the issue of cultural heritage area restructuring that has not touched the architectural objects and the designing of coastal city. 
Semarang City is a city that has existed since the late 14th century and was visited by Tome Pires, Zheng He's Fleet, and Ma Huan (Cortesao, 1944). While old cities (First Map of Old Java Island - lava Maior Works Barent Langenes 1612) and travel journey of foreign seafarers in the 16th century, as well as historical record from Tome Pires and Mahuan (Cortesao, 1944), mentioned that they have visited several cities-city along the north coast of Java. The existence of these cities is now losing its identity as a traditional city due to the pace of development and flood/rob disasters. Therefore, this research will provide a new idea about coastal heritage area as a cultural heritage which can be implemented as planning, exploiting, supervising and controlling coastal area to fill the unexplained detail in Law Number 32 the year of 2014 on Marine. (Article 43 paragraph 1 on coastal zone zoning planning). Similarly, these findings are expected to fill the gap of knowledge from Central Java Province Regulation No. 6/2010 concerning Spatial Planning of Central Java Province Year 2009-2029 Articles 30 and 31, on the Province Spatial Patterns that describe the planned distribution of protected areas (it is explained that one of the protected areas is a cultural heritage area). This finding is also expected to provide more detailed input to challenge the cultural heritage zone for Law No. 5 of 1992 on Heritage Objects. The contribution of the research is to fill the gap of knowledge about the coastal heritage area that has not been detailed in Law Number 32 the year 2014. Thus, the final result of this research will be useful as an effort to arrange, control and secure the cultural heritage area in the coastal area. The knowledge obtained is used to be applied by the Tourism Department in the development of heritage tourism.

In the cultural heritage law, it is stated that cultural heritage objects are man-made objects, representing a distinct style and representing a stylistic period of at least 50 (fifty) years, and are considered to have important values for history, science, and culture. Semarang coastal city site is a location containing or speculated in containing objects of cultural heritage because it has existed since the end of the 14th century (Cortesao, 1944; Rukayah, Dhanang, et al., 2016; Soekirno, 1956; Tio, 2004). At that time, the old city center of Semarang was on the beach. Its existence nowadays is no longer in the coastal area (located in the middle of the city due to the phenomenon of ocean accretion). This paper aims to find architectural buildings and city patterns as coastal markers of the old city of Semarang. Protection of cultural heritage objects and sites aimed at preserving and utilizing them to promote Indonesia national culture in order to improve the national character building. Even with the rapid development of the city area, Semarang also needs to maintain its identity, dignity, and heritage (Amin \& Kurniawan, 2020). Culture cannot be separated from the process of adaptation to the environment (Arini Estiastuti et al., 2019).

The coastline of Semarang in the 15th century is at what is now called Kampung Melayu or Melayu Village in Sleko region (old Photograph from Atlas Mutual Heritage) (Bemmelen, 1948). This village became the first disembarkation area to enter Semarang (Soekirno, 1956; Tio, 2004). The old evidence stating that Semarang was a former port or a coastal city is only based on historical approaches and coastal geology (Parman, 2010; Sardiyatmo, 2013). How do the architecture and urban design approaches complement the statement above?

Kampung Melayu is located at the estuary of Semarang River precisely on the north side of the traditional city center of Semarang or commonly known as Kanjengan, Kanjengan means the head office of the government for kanjeng / sultan in Java. At that time, Kampung Melayu (14th century) and the former city center of Semarang in Bubakan (15th century), Gabahan (1659 AD), Sekayu (1666 AD) and Kanjengan (1770 AD) were located along the river (Rukayah, Respati, et al., 2016). Between the seaport-Kampung-Melayu (Javanese nagory) and the Kanjengan square are the road corridor connecting these areas (Atlas Mutual Heritage map of 1719) (Rukayah \& Sahid, 2017). 


\section{Methods}

The method that will be used is the historical method (extracting information from old maps and old pictures) and naturalistic methods in order to discover the conditions in the present of Semarang. Assistance with aerial photographs through satellite imagery is required in series to check the progress from year to year. Similarly, photographs using drones are indispensable especially for data collection of heritage buildings that still exist. Interviews with old building owners are needed to find appropriate conservation action proposals in the future. The policy method is needed in the third phase of research to find the knowledge that can be applied by the stakeholder in this case the Province Tourism Office, Province Maritime Office and Development Planning Agency at Sub-National Level or commonly known as Bappeda Semarang.

To obtain data about Semarang in the 15th-17th century AD, it required old data. The Dutch colonial government in Indonesia had collected maps, archives, photographs and manual sketches about the culture, architecture, and conditions of Indonesia in the past. Maps and images available from KITLV.nl, tropen museum and atlas mutual heritage are maps. However, the availability of the old maps, pictures or photographs related to this area condition in the late 16th century is very limited. Another limitation is that the form of the local city center is less clearly described although the Dutch colonial fortress was built close to this site.

In order to complement the shortage, the comparisons of historical articles, foreign travel stories and local traveler stories (Jayengresmi in Serat Centini) should be conducted (Noorduyn, 1982). Serat Centini is an ancient book that tells about Raden Jayengresmi and his students around cities on Java's island. He is Sunan Giri's son, one of the names of wali songo (propagator of Islam) in Indonesia.The lack of Indonesia history (Kuntowijoyo, 1994) therefore requires the reading of old maps and pictures using seeing by believing approach (Pole, 2004). The analysis was using manual sketches and urban design (Moughtin, 1999). Survey approach in the field was conducted to obtain the toponym data, architecture and urban design in the past that still exist in the present. Toponym is the name of the place that has its original meaning (Asadi, 2015). Toponyms serve as symbols of regional culture and thus reflect the history, habitat and environment of a place (Qian et al., 2016). Toponym has its own value as an object of academic study, from various perspectives including linguistics, philosophy, history, geography, and archaeology. (Lauder \& Lauder, 2015). The toponyms and patterns of the traditional city of the Islamic Sultanate can be the references in looking for patterns of other cities in Java (Adrisijanti, 2000). The use of strategies in analysing texts using critical toponyms and critical discourse analysis to an explanation of the toponym concept of traditional coastal city architecture (Nurhayati, 2018).

\section{Theory Gap}

There is still a gap of knowledge about coastal area detail from the architecture science and urban design point of view. The knowledge of coastal Semarang in the past has become important to reveal the existence of architecture and heritage cities. The area inventory and heritage architecture are conducted as it is feared not gaining a special attention in the planning, arranging and controlling in zoning of the coastal area. In zoning plan, the coastal areas and small islands are implemented in accordance with the Law Number 27 the year 2007 jo. Law No. 1 of 2014 on the Management of Coastal Zones and Small Islands, Local Governments are obliged to prepare the Zoning Plan for Coastal Zone and Small Islands or it can be called RZWP-3-K. In the preparation of the zonation, of course, needs to be found and does some data collection of architecture and the city as a legacy of the past to make efforts proposed appropriate conservation actions. 
Cities on the coast of Java in the past have been recorded and mapped in pictures. On the map of the first old island of Java - lava Maior the work of Barent Langenes 1612 and travel journal of 16th-century foreign seafarers, as well as a historical journal from Tome Pires and Mahuan (Cortesao, 1944) mentions that there are several cities along the north coast of Java. The existence of these cities is now losing their identity as the traditional cities due to the sedimentation rate. It also occurs in Semarang City.

Semarang City is a city that has existed since the late 14th century and was visited by Tome Pires, Zheng He's Fleet, and Ma Huan.(Cortesao, 1944). The theory of van Bamelen, 1948, which states that the coastline of the 15th century of Semarang is located in the Sleko region (Tio, 2004) or right on the north side of the Jurnatan area in the present day. Similarly, the city of Demak Kingdom (1478-1518), $30 \mathrm{~km}$ to the East of Semarang, which by foreign seafarers is mentioned on the seashore. (Ma Huan, Tome Pires)

The second gap of knowledge is found in Central Java Province Regulation No. 6/2010 concerning Central Java Province Spatial Plan of 2009 - 2029 Provisions 30 and 31, namely the Province Spatial Pattern describing the planned distribution of protected areas (in the following is described that one of the protected areas is a cultural heritage area). The cultural heritage area in Law No. 5 of 1992 concerning Objects of Culture is a man-made object, representing a distinct style period and representing a stylistic period of at least 50 (fifty) years.

Thus, the existence of the coastal city of Semarang that has existed since the late 14th century is a region of human-made cultural conservation, representing a distinct style and representing a style of more than 50 (fifty) years. In the area is very necessary to conduct a mapping, data collecting both in terms of architecture and urban design as an effort to approach the proposed conservation measures to support the heritage tourism.

\section{Discussion}

\subsection{The Old City of Semarang and the Glory of Semarang River}

Referring to the map of 1619 from Atlas Mutual Heritage and the subsequent map from kitlv, the authors found that it is more appropriate to say that the old city of Semarang is an area built by native peoples and immigrants as well as the center of the native governmental center in the nineteenth century. Indeed, there is a distortion that the old city of Semarang is a fortress built by Dutch colonials like other cities under Dutch colonial rule, the fort was built as a military center was established, possibly after 1741 or before 1756. Some old maps of Semarang old from the year 1619, 1719, 1800, 1875, 1880 seen the existence of indigenous settlements, Chinatown 1412

According to M. A. Budiman (2013), along Semarang River, October 13, 2014, the upstream of the river is not derived from a 1water source such as Bengawan Solo River whose springs are sourced in the Seribu Mountains. Rather sourced from Kaligarang River that flowed through the water gate in the Barusari Village, or exactly located on the right side Pleredan. The water flows through two channels to the left of Dr. Soetomo Street. Most of the water flows through the river behind Wonosari Flower Market (below Bergota hill), continues into the channel behind Lawang Sewu, Batanmiroto Village, Kampung Sekayu, Jagalan, Chinatown, Mberok, Jalan Layur, and ends in Kalibaru (old port of Semarang which is on the right and the left there are a number of warehouses such as the Marabunta veem).

Kali Baru or Baru River area above is referred to the area around Kampung Melayu / Sleko. Semarang River experienced its glory in the early days when the river gate was a strategic area for foreign seafarers to land the boat and settle there. The boat settles place is now called 
Kampung Ndarat. It is a multi-ethnic settlement for Arabian, Chinese, Handramaut, Malayan, and Banjar.

At the following glory of the Dutch colonial era, this river became one of the economic pulses that could be navigated small type of vessels up to the inside area for example to the area Pedamaran (formerly a market, it is united into Johar market now). The name Damar is derived from the type of goods that are traded camphor and resin. Likewise, glory was obtained during the heyday of the sugar empire Oey Tiong Ham (between 1850-1900). In the left and right of Semarang River, there were warehouses of sugar storage. In this river, small boats or barges carried sugar and other commodities to be transported to the port of Semarang before sent to various continents.

In the past, the width of Semarang River reached about 60 meters. The width of the river was slowly diminishing with the occurrence of sedimentation and the loss of the water sources that had become part of the upstream of the river in the past. Now the width of the River / Kali Semarang. Only 16-20 meters and the water surface is not more than $50 \mathrm{~cm}$.

Semarang coastal city with multi-ethnic settlements at the estuary of Semarang River, as a multi-ethnic people settled, is a lot of artefacts and interesting architecture of the city which left. Many cities that are called as a metropolitan city at that time became the material to be written by the foreign seafarers when they travelled and stopped by in some countries including in the archipelago. Some of the travel journals that mostly used as a reference material are the Tome Pires entitled The Oriental Suma. Some seafarers are even skilled in sketching/portraying the condition of the seaport cities as a crowded port (Valentyn, Lowdewick, Odorico, and Johanes Racht). However, as the limited time to stop by or anchor then they created the travel journal at a glance only.

There have been many researchers who studied about the river, yet they tended to the physical aspect of the river itself. Not many researchers/experts examined the architectural and urban aspects that grow around the city and along the river as the path of the metropolitan city circulation at that time. The river has a function as the main highway connecting the city with the inland or vice versa. It is not surprising that the city of the old city built on the river.

\subsection{Semarang in 15th Century}

In the past, Semarang old city (referring to photos of KITLV, the old Semarang is the area of Layur and Kampung Melayu at the estuary of Semarang river) allegedly located on the coastline (Bemmelen, 1948; Rukayah, Dhanang, et al., 2016). In case that it is true then the results of research from architecture and urban design perspective will complement the revelation of the historians and geologists. Historical and architectural value needs to be secured from land subsidence, natural disasters and the pace of development. According to the historical record, Semarang city is a city that has existed since the 8th century was visited by Tome Pires, Zheng He's Fleet, and Ma Huan (Cortesao, 1944). Semarang city at that time according to Bemmalen, 1949 is still a group of islands. The coastline is in the temple area. In the 14th century, the coastline progressed to Sleko (Cortesao, 1944). In the area is marked by the multi-ethnic village.

Meanwhile, in the old map (Map of Old Java Island First - lava Maior Works Barent Langenes 1612) and journey record of foreign seafarers of the 16th century, as well as historical journal from Tome Pires and Mahuan (Cortesao, 1944) mentioned that they have visited several cities along the north coast of Java but had not mentioned the city of Semarang on the map. The existence of old cities depicted on the map of the 16th century Java Island is losing its identity 
as a traditional city now, due to the rate of sedimentation, abrasion or the pace of development. Another evidence is that from Semarang to Demak can be passed through the sea, it is the historical record of wood delivering for the construction of the Demak mosque that flowed from Semarang to the Java Sea to Demak. Before the discovery of the marine geological map at that time (figure 2) it is difficult to accept the story. As in the present, to go to Demak, we can go through land travel. The evidence is very strong to reveal the past conditions of Semarang city and Demak city role as the coastal cities.

Semarang city is also stated on the travel journal record of the wanderer in the Past. The wanderer/adventurer journal record in the 15th century has a very significant role in exposing the existence of civilization in the coastal areas they visited in the past. The cities on the north coast of Java are listed as port cities and ports such as Bantam, Calava, Cheribon, Tegal, Pcalongan, Samarang (Semarang), Damma (Demak), Japara, Rembang, Touban, and Surabaya. There is also a record of Semarang city with the name Pragota (Pires \& Rodrigues, 1990).

An old sketch/painting by Johannes Racht about the city of Semarang, 16th century, described the condition of the indigenous city center of Semarang. Semarang city is also listed in local traveler journal record such as Bujanggga Manik (1627) from Sundanese. He recorded his wanderings to the East of Java and called Padanara area located on the coast and the mountains on the Southside. This location matched the description of Semarang city. Padanara word refers to the name of the city leader who was named Kyai Ageng Pandanaran. While in Serat Centini, 1814, Jayengresmi told about the wandering in several cities in Java. He departed from Giri as the starting point of his travels to several cities and arrived in the Demak city (Bintoro and Prawata hill). It can be concluded that the city of Demak and Semarang have a close distance (the local land travel stories of a local wanderer) and the city of Demak and Semarang are the bustling port cities (the journey record of foreign seafarers). These two data are the evidence that both of the cities played a role as a port city in the past.

The ports in Semarang were in the Kampung Darat, the Kampung Melayu at Sleko in 1480 (Joe, 2004) (Soekirno, 1956) and in Demak Sultanate functioning as the international airport since 1475 (Rahardjo, 1997; Wahby, 2007). At that time, Semarang was the subordinate city of the Sultanate (Islamic sultanate and International seaport at that time). Demak was in the Muria Strait approximately $30 \mathrm{~km}$ to the East of Semarang. Merchant ships from Semarang could take a shortcut to Rembang via Demak. However, in the 17th century, the strait was no longer navigable (Bemmelen, 1948; Graaf De H.J And Pigeaud, 1985; Lombard, 1996; Rahardjo, 1997). The old pictures, research results and old sketches below prove that Demak was located on the coast.

Another evidence proving that there was a seaborne transportation from Semarang to Demak is the historical record about the wood shipment for the construction of the Demak Mosque, from Semarang to the Java Sea, and then to Demak. Before the discovery of the marine geological map of this period (figure 2), it was difficult to accept the story because in the present, to go tp Demak could be conducted using the land transportation. The evidence strongly reveals the past conditions of Semarang, together with the Demak, played an important role as a coastal city.

\subsection{Semarang in Seafarers' records in the Past}

The records of international seafarers in the 15th century have a vital role in exposing the existence of civilization of the coastal areas of the past. The recorded coastal cities in Northern Java were Bantam, Calava, Cheribon, Tegal, Pcalongan, Samarang (Semarang), Damma 
(Demak), Japara, Rembang, Touban, and Surabaya, and there is also a record of the Old Semarang called Pragota

An old sketch of Johannes Racht's work about the city of Semarang in the 16th century describes the local central city of Semarang. (see figure 4.3.1).

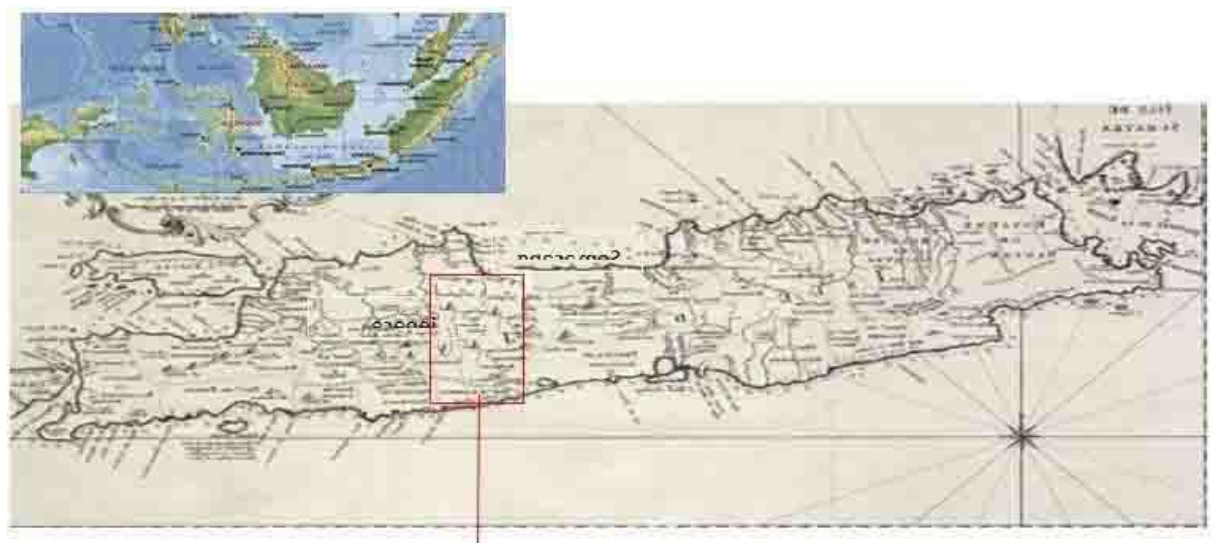

Figure 4.3.1 The 1724 Map shows the strait that has formed a river (Atlas Mutual Heritage, 2021)

The city was also recorded by local traveler such as Bujanggga Manik (1627). He recorded the existence of an area called Padanara located on the coast with mountains on the Southside. This location is in accordance with the description of Semarang. Padanara word also refers to the name of the city leader called Kyai Ageng Pandanaran. In Serat Centini, 1814, it was told that the city of Demak (Bintoro and Prawata hill) often suffered flood in the rainy season. It can be concluded that the Old Semarang was a mountainous town on the beach and was a bustling port.

\subsection{Toponym relics}

Semarang as a port is characterized by the name of the village with the toponym called Kampung Darat (Ndarat - Javanese language) which means a land where foreign merchant ships docked. The site is thought to have existed when the village became a place for foreign seafarers in the late 14th century to stop by. The bustling harbors in Kampung Darat and the emergence of the multi-ethnic's village at this region made Pangeran Made Pandan (Sunan Pandanaran I) as the preacher of Islam in the Pragota area, he moved the center of activities close to this area. Selected areas on the East side of the Semarang River which was later became known as the Bubakan. (Fig. 2.a). Bubakan means opening a new area. (Budiman, 1978).

The role of the Kampung Darat diminished in 1743 when the Dutch moved the Port Mangkang to the Boom Lama area (Boom means a port in Dutch) in Kampung Melayu. Nevertheless, the Dutch set up a new canal in 1873 (to straighten the winding river in Semarang) and moved the port in Boom to the present area (Liem, 2004). From the toponyms and old maps of Semarang, we can find some evidence that indicating this area was once a natural port. A protected bay between small islands (8th-century sketches of Semarang) in its development narrowed and became an estuary that connecting the trade in Semarang city to the trade in the Mataram Kingdom in the interior of Java. (Map of Semarang in 1789). 


\subsection{Architectural Heritage}

The arrival of many nations such as Arabic, Chinese, Malay, Gujarati, and Yemen to the region was marked by the various forms of home architecture and shops/shop houses and the Menara Layur Mosque. The mosque was built in 1743 by Islamic scholars and traders from Hadramaut (Yemen). The technology applied to build the wall of the tower was unknown among the locals at that time. The approximately 4-5 storey minarets served as lighthouses. The way to the mosque in the past could be accessed from the river (picture 4). This mosque can be regarded as the only building that characterized Semarang as a coastal city at that time. (see Fig, 4.5.1)

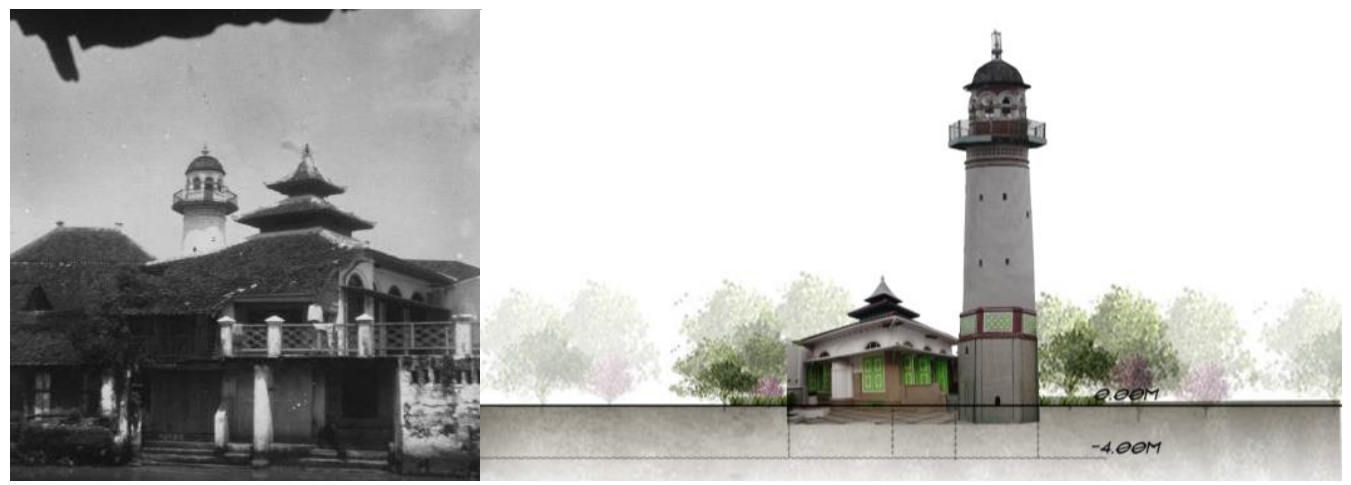

Figure 4.5.1 The Layur Mosque with access from the river. (Atlas Mutual heritage and author sketch)

With the construction of the post weg groot line in 1809-1811 on the south side at Jalan Layur, the orientation of the building was no longer toward the river, and the river no longer became the transportation path (Pratiwo.P.Nas, 2002). Field surveys found that the remaining buildings found along this street that now are in the form of houses, shop houses and shops are dominated by Chinese and Arabian. Based on field surveys and old literature 'Buku Dagang Kota Semarang 1956', it was revealed that until the 1970s, there were many shops and commercial centers in Semarang at Jalan Layur.

\subsection{Urban Design Heritage as the River Front and Coastal city}

Referring to the simple map sketch made in 1600, there is an area called Pabean connected to the government center area in Kanjengan by a line. Meanwhile, on the map of 1719 , it is written that Javanese energy was connected by a line to Paseban (square) and Dalem. From the two maps, it can be interpreted that the central structure of the Semarang City at that time had the port-local kampong-corridor-government center pattern. This pattern is similar to the urban design patterns of cities in Java. The following maps are the compilation of Semarang map in 1789, a map from Tillema and the present that illustrate the port-corridor/north axis-the square and the regency as the central government (see fig 4.6.1 and 4.6.2) 


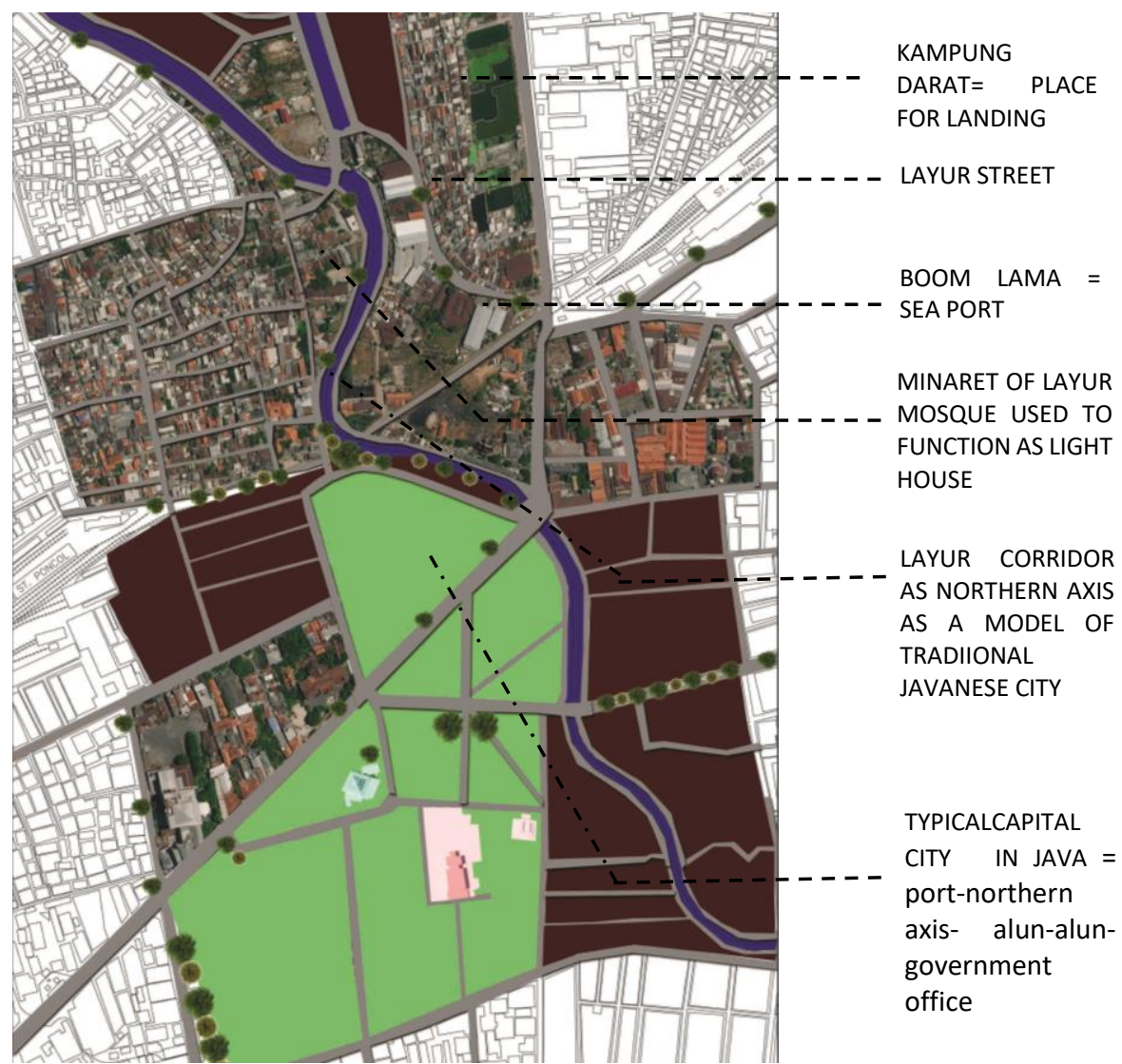

Figure 4.6.1 Model of Old coastal city. (Author Sketch, 2021)

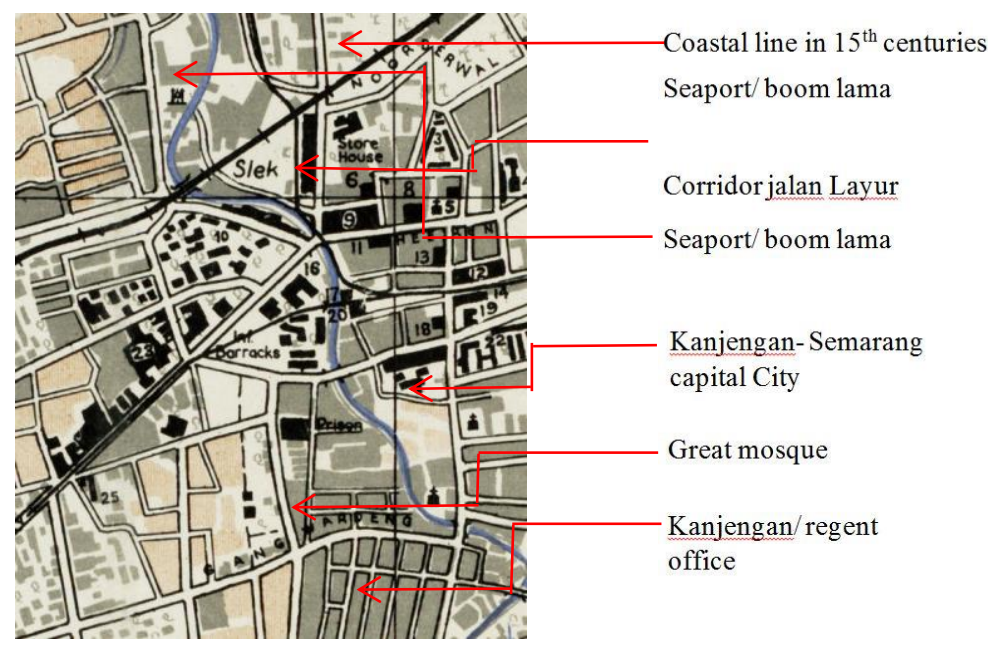

Figure 4.6.2 Position of the Layur corridor against the old map. (KITLV, 2021)

Referring to the sketch of a 1600 simple map, in the area, it is written that the institute linked to a line on the current road to the central government in Kanjengan. Meanwhile, on the map of 1719 is written that Javanese connected by a line to paseban (square) and Dalem. According to the two maps, it can be interpreted that the central structure of the Semarang city, at that time, has a pattern of ports-indigenous villages-corridors-central government. The pattern is similar to the urban design patterns of mostly cities in Java. In the following is a 
compilation of the Semarang city map of 1789 , a map sourced from Tillema, and a map in the present that illustrates the pattern of the Port-corridor / north axis-alun-alun (open space) and the regency (central government).

\section{Conclusion}

Semarang as the former coastal city has evidence indicated by the existence of the former lighthouse (the Menara Layur Mosque), multi-ethnics houses, toponyms indicating that some places were a former harbor and the remaining trade corridor connecting the port and the local government center. The location of the old coastal Semarang was in accordance with the theoretical statement of the Dutch geologist who states that the position of the 14th century coast was in this area (Bemmelen, 1948), Semarang historian also stated that Semarang was located in the vicinity of the land village and old port Semarang located in Kampung Darat (Liem, 2004), According to Tio (2001), the Semarang Lama coastline is located in Kampung Melayu in Sleko. Based on a map from 1695 that the century coastline is in this area (Rukayah et al., 2018).

The coastline is getting more advanced because of the sedimentation process causing this area is isolated from the sea. The life of the community as a sailor or fisherman is not found anymore. The remaining shops in Jalan Layur sell various fishing equipment without any place to catch fish other than in the river. This natural sedimentation process is similar to coastal reclamation activities aimed at expanding the land to the sea. A valuable lesson is the design of the city / coastal reclamation so as not to block the coastal areas that have been present before.

The evidence that Semarang as an ex-coastal city is shown by the ex-lighthouse building (Menara Layur mosque), the remaining toponym that directed the ex-seaport and the rest of the trade corridor connecting the ports and the native government center. This concept is similar to the Islamic sultanates of the northern coast of Java and the waterfront city of Java. As the city of Islamic propagated by Ki Ageng Pandanaran in the early 15th century (the first regent of Semarang appointed by Sultan Demak) it seems that the city planning concept refers to the city of Demak Sultanate (tahun 1478) which in the past was located on the coast of the Muria Strait. Thus Semarang and Demak cities have similarities in the pattern of urban planning.

Semarang as a seaport is characterized by the name of a village with a toponym called Kampung Darat (Ndarat - Javanese language) which means a land where foreign merchant ships anchored. The site is thought to have existed when the village became a place of foreign seafarers at the end of the 14th century for a stopover.

The bustling port of Kampung Darat and the emersion of multi-ethnic villages in this area encouraged Panderan Made Pandan (Sunan Pandanaran I), as an Islamic priest in the Pragota area, changed into the activity center close to this area. The selected area on the east side of the Semarang River is known as the Bubakan. Bubakan means opening a new area (A. Budiman, 1978). Another toponym is the old boom area. Boom means a seaport in the Netherlands. Lama means old in Java.

Based on the compilation of Tillema's old maps and the recent maps, it is found that the Layur Corridor is directly connected to the city center government. Kanjengan city center consists of open space / squares, mosques, Kanjengan office and a prison Based on Toponym analysis, the rest of the architecture and urban structure model in Java where the pattern of the city is the corridor the city government, therefore the position of Malay kampong is in the coastal area of Semarang in the past 
The coastline is further due to the sedimentation process that causes this area to be isolated from the sea. The life of the community as a sailor or fisherman is not found anymore. The remaining stores on Jalan Layur sell a variety of fishing equipment with no place to catch the fish other than in the river. This unification process is similar to coastal reclamation activities aimed at expanding the land to the sea. A valuable lesson is the city/beach reclamation design to avoid the existing coastal areas to be blocked.

This finding enriches the knowledge and theories about the shape of the old city center of Semarang which is similar to the central city of the sultanate in the coastal area of Demak city.

An understanding of the city history is crucial for urban planners and designers. Most urban planning techniques focus less on the wisdom of the past urban designs that were from the pattern of coastal cities. The pattern of coastal city/waterfront city in Semarang shows strong evidence that this city was a coastal city, but this pattern now has lost due to the sedimentation. What has happened to this city can be the case for other coastal cities recorded in historical articles and the records of sailors in the past. Conservation efforts to the remaining buildings and coastal cities urban design created by locals are important because they have contained values of local wisdom as the main gate and the barrier of the center of government to the bustling area.

\section{Acknowledgments}

The authors express their gratitude to the Ministry of Research and Technology and the Research and Community Services of Diponegoro University for the given financial supports Riset Pengembangan dan Penerapan (RPP) with the funding research contract number 18556/UN7.6.1/PP/2021.

I would like to thank to the Office of Marine and Fisheries of Central Java Province which has provided map information and about zoning plan of the coastal area. Researchers have been given the opportunity to be resource persons in several meetings in the coastal city of Semarang and Rembang. In the socialization activities, the researcher has conveyed and gave input about the importance of heritage area mapping in the coastal arrangement.

\section{References}

Adrisijanti, I. (2000). Arkeologi Perkotaan Mataram Islam. Yogyakarta: Jendela.

Amin, S., \& Kurniawan, G. F. (2020). Semarang cultural ecology in the grip of capitalism. IOP Conference Series: Earth and Environmental Science, 485(1). https://doi.org/10.1088/1755-1315/485/1/012048

Arini Estiastuti, A., Estiastuti, A., Nurharini, A., Bektiningsih, K., \& Munisah, M. (2019). Cultural Heritage to Build History for Life in Social Science Learning at Primary Schools. 5th International Conference on Education and Technology (ICET 2019), 382(Icet), 310-317. https://doi.org/10.2991/icet-19.2019.78

Asadi. (2015). Nama Rupabumi, Toponim, Aturan dan Kenyataan. Jurnal Lingkar Widyaiswara, 2(4), 18-35.

Bemmelen, R. Van. (1948). Geology of Indonesia Vol-IA General. Nederland: Government Printing Office.

Budiman, A. (1978). Semarang Riwajatmoe Doeloe. Semarang: Tanjung Sari.

Budiman, M. A. (2013). Semarang Tradition: Dugderan. Prosiding The 5th International Conference on Indonesian Studies: "Ethnicity and Globalization"Th International Conference on Indonesian Studies: "Ethnicity and Globalization," 69-75.

Cortesao, A. (1944). The Suma Oriental of Tome Pires: An Account of the East, from the Red 
Sea to Japan, Written in Malacca and India in 1512-1515. Hakluyt Society Series.

Graaf De H.J And Pigeaud. (1985). Graaf De H.J and Pigeaud. 1985. Kerajaan-kerajaan Islam di Jawa. Peralihan dari Majapahit ke Mataram. Pustaka Utama Grafiti dan KITLV (first published 1974).

Jafar Rouhi. (2017). Definition of Cultural Heritage Properties and Their Values By the Past. Asian Journal of Science and Technology, 08(December 2017), 7109-7114.

Kuntowijoyo. (1994). Metodologi Sejarah. Yogyakarta: Tiara Wacana.

Lauder, A. F., \& Lauder, M. R. M. T. (2015). Ubiquitous place names: Standardization and study in Indonesia. Wacana, 16(2), 383-410. https://doi.org/10.17510/wjhi.v16i2.383

Liem, T. J. (2004). Riwayat Semarang. Semarang: Hasta Wahana.

Lombard, D. (1996). Nusa Jawa: Batas-batas pembaratan (Vol. 1). PT Gramedia Pustaka Utama.

Moughtin, C. (1999). Urban Design Methode and techniques. Oxford: Architectural Press.

Noorduyn, J. (1982). Bujangga Manik's journeys through Java; topographical data from an old Sundanese source. Bijdragen Tot de Taal-, Land-En Volkenkunde/Journal of the Humanities and Social Sciences of Southeast Asia, 138(4), 413-442.

Nurhayati, N. (2018). Toponymy and Branding of Modern Residential Sites in Semarang. E3S Web of Conferences, 73, 1-4. https://doi.org/10.1051/e3sconf/20187308021

Parman, S. (2010). Deteksi perubahan garis pantai melalui citra penginderaan jauh di Pantai Utara Semarang Demak. Jurnal Geografi: Media Informasi Pengembangan Dan Profesi Kegeografian, $7(1)$.

Pires, T., \& Rodrigues, F. (1990). The Suma Oriental of Tome Pires, Books 1-5 (Vol. 1). Asian educational services.

Pole, C. J. (2004). Seeing is believing?: Approaches to visual research. New York: Emerald Publishing Limited.

Pratiwo.P.Nas. (2002). Java and De Groote Postweg, La Grande Route, the Great Mail Road , Jalan Raya Pos. 158, 707-725.

Qian, S., Kang, M., \& Weng, M. (2016). Toponym mapping: a case for distribution of ethnic groups and landscape features in Guangdong, China. Journal of Maps, 12, 546-550. https://doi.org/10.1080/17445647.2016.1201017

Rahardjo, S. (1997). Kota Demak sebagai bandar dagang di jalur sutra. Jakarta: Depdikbud.

Rukayah, R. S., Dhanang, R., \& and Endang, S. (2016). Morphology of Traditional City Center in Semarang: Towards Adaptive re- use in urban heritage. Environment-Behaviour Proceedings Journal, 1(4), 109-118.

Rukayah, R. S., Respati, P. D., \& Susilo, S. E. S. (2016). Morphology of Traditional City Center in Semarang: Towards Adaptive re- use in urban heritage. Environment-Behaviour Proceedings Journal, 1(4), 109-118. https://doi.org/10.21834/e-bpj.v1i4.91

Rukayah, R. S., \& Sahid, M. (2017). Menemukan Sumbu Utara Selatan Alun-alun Lama Kanjengan Sebagai Dasar Perencanaan Pusat Kota Semarang Berdasarkan Heritage.

Rukayah, R. S., Susilo, E. S., \& Abdullah, M. (2018). Semarang Kota Pesisir Lama. Yogyakarta: Tekno Sain.

Sardiyatmo, S. (2013). Kajian Perubahan Garis Pantai Semarang dengan Foto Udara Pankromatik Hitam Putih. Ilmu Kelautan: Indonesian Journal of Marine Sciences, 9(3), 160-168.

Soekirno. (1956). Semarang. Semarang: Djawatan Penerangan Kota Besar Semarang.

Tio, J. (2001). Kota Semarang dalam kenangan. J. Tio.

Tio, J. (2004). Kota Semarang dalam Kenangan. Semarang: Dinas Provinsi Jateng.

Wahby, A. E. I. (2007). The Architecture of the Early Mosques and Shrines of Java : Influences of the Arab Merchants in the 15th and 16th Centuries ? 1, 1-205. 